\title{
Uma reflexão teórica: epistemologia e a didática das ciências na formação de professores como "epistemólogos auxiliares"
}

\author{
Santos, Karina N. ${ }^{1}$, Santos, Bruno F. ${ }^{2}$
}

\section{Resumo}

O presente artigo tem como objetivo desenvolver uma reflexão teórica sobre as interfaces entre a Epistemologia e a Didática das ciências, reafirmando a necessidade de se incluírem estudos da Epistemologia nos cursos de formação de professores, tendo em vista que a Epistemologia contribui como um dos pressupostos para uma formação mais crítica e para a superação da concepção empírico/indutivista que ainda predominante nessa área. Essas questões correspondem às concepções epistemológicas que, apesar de darem significado à prática docente, têm sido pouco trabalhadas nos cursos de formação de professores. Este artigo visa contribuir para a reflexão sobre a formação docente, destacando a importância das questões epistemológicas para uma formação mais crítica cientificamente e filosoficamente.

Palavras-chave: epistemologia, ensino de ciências

\section{Summary}

This article show a theoretical reflection on the interfaces between Epistemology and Didactics of Science, reaffirming the need to include studies of epistemology in teacher education courses in order to contribute as an Epistemology of the assumptions for training and a more critical for overcoming the empirical design / inductivist still prevalent in this area. These questions correspond to epistemological concepts that, even though they give meaning to the teaching practice have been little worked in teacher training courses. This article aims to contribute to the reflection on teacher training, highlighting the importance of epistemological issues critical to a more scientifically and philosophically training.

Keywords: epistemology, science education

\footnotetext{
1,2 Universidade Estadual do Sudoeste da Bahia. UESB, Rua José Moreira Sobrinho, s/n. Jequiezinho, Jequié, Bahia, Brasil. CEP: 45206-190, +55 (73) 8807-4437.karina_novaes@ymail.com
} 